\title{
DESIGN AND ANALYSIS OF BOOST CONVERTER WITH CLD CELL
}

\author{
Selvakumar. $\mathbf{R}^{1}$, Vignesh. C. $\mathbf{J}^{2}$, Gayathri Deivanayaki. V. $\mathbf{P}^{3}$, Naveena. $\mathbf{P}^{4}$ \\ ${ }^{I}$ PG-Student, Power Electronics, BIT, Sathyamangalam, Tamilnadu, India \\ ${ }^{2}$ PG-Student, Power Electronics, BIT, Sathyamangalam, Tamilnadu, India \\ ${ }^{3}$ PG-Student, Power Electronics, BIT, Sathyamangalam, Tamilnadu, India \\ ${ }^{4}$ PG-Student, Power Electronics, BIT, Sathyamangalam, Tamilnadu, India
}

\begin{abstract}
In this paper, the output voltage in renewable energy sources is improved by using DC-DC converter topology. Basically Boost converter is used for improving the voltage gain. In this converter switching frequency is limited, hence the output voltage is reduced. To overcome this issue, by using the boost converter with CLD cell is proposed.In this proposed paper for comparing the voltage stress and efficiency by using two converters topology. For the duty ratio of 0.5 the output voltage is compared with the conventional boost converter.
\end{abstract}

Keywords- Boost converter, Boost Converter with CLD, Voltage stress.

\section{INTRODUCTION}

In recent years for a great number of appliances dc-dc converter topology is employed. Normally in renewable energy system, the system having low output characteristics to recover this demand DC-DC converter topology is implemented. For maintaining the dc output voltage range in PV array and fuel cells, converter can be used to improve the output voltage. But during the switching operation the voltage stress will be raised. While choosing the converter the concentrating features are; when switch is turn on it must attain the zero voltage crossing, when Photovoltaic array is connected to the grid the converter should provide the high terminal voltage for low input range. The converter which gives the high output range at low voltage stress is more efficient.Voltage gain generally based on the duty ratio hence by choosing the passive components the duty cycle ratio can be limited [7].

\section{BOOST CONVERTER}

Boost converter is used to step up the given voltage to the desired voltage. The input to this converter may be from any DC source like rectifiers, solar panel,battaries etc,. The circuit diagram for Boost Converter is shown below,

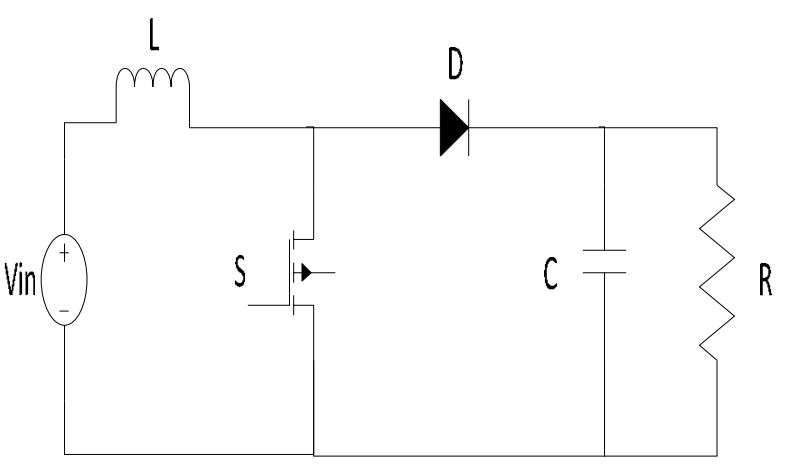

Fig-1: Circuit diagram for Boost converter Two modes of operations are there,

\section{Mode 1:}

When the switch $\mathrm{S}$ is closed the inductor gets charged through the supply voltage and stores the energy. In this mode inductor current increases gradually, but we assume that the charging and the discharging of the inductor are linear. The diode blocks the current flowing and so load current remains constant which is being supplied due to the discharging of the capacitor.

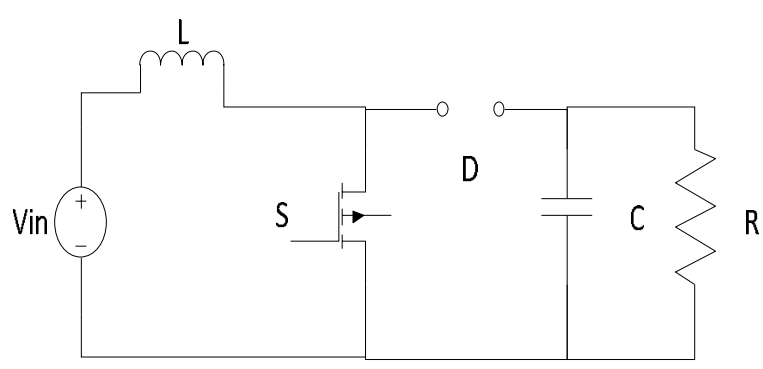

Fig-2: Circuit Diagram for Mode 1 Operation

\section{Mode 2:}

When the switch $\mathrm{S}$ is open, the diode becomes forward biased. The energy stored in the inductor changes it polarity todischarge through diode and charge the capacitor. Now, the capacitor supplies voltage to load.The load current remains constant throughout the operation.

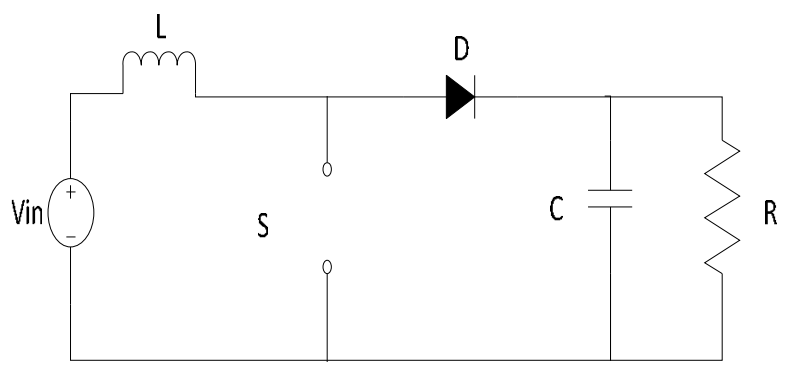

Fig-3: Circuit Diagram for Mode 2 Operation 


\subsection{Output Equation for Boost Converter}

The voltage-current relation for the inductor $\mathrm{L}$ is, $i=\frac{1}{L} \int_{0}^{t} V d t+i_{0}$ Or $V=L \frac{d i}{d t}$

When the switch is turned on,

$\Delta i=\frac{\left(V_{\text {in }}-V_{\text {Trans }}\right) T_{\text {on }}}{L}$

When the switch is turned off, $\Delta i=\frac{\left(V_{\text {out }}-V_{\text {in }}+V_{D}\right) T_{\text {off }}}{L}$

By equating the $\Delta i$, we can solve the $\mathrm{V}_{\text {out }}$

$$
V_{\text {out }}=\frac{V_{\text {in }}-V_{\text {Trans }} \delta}{(1-\delta)}-V_{D}
$$

Neglecting the voltage drop across diode $V_{D}$ and transistor $V_{\text {Trans }}$,

$V_{\text {out }}=\frac{V_{\text {in }}}{(1-\delta)}$

\subsection{Simulation results for boost converter}

The Boost converter is simulated by using MATLAB 2013 and the circuit is shown in Fig.4. The input voltage given to the circuit is $10 \mathrm{~V}$ and it works on $1 \mathrm{kHz}$ switching frequency.Duty ratio $(\delta)$ is varied to boost the output voltage in desired value.

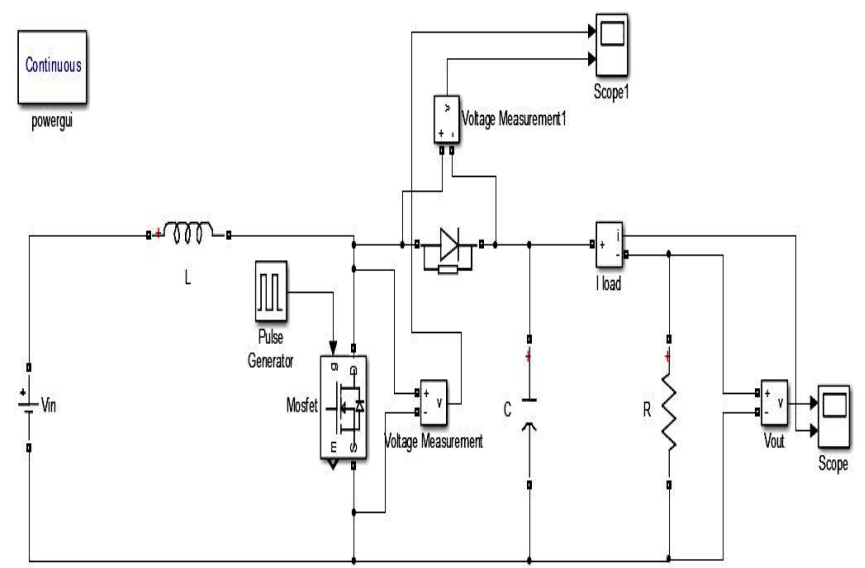

Fig-4: Simulation Circuit for Boost Converter

The inductor values for the converter is designed by using the formula given below,

$L=\frac{(1-\delta)^{2} \delta R}{2 F_{S}}$

Where,

$$
\begin{aligned}
& \delta=\text { duty cycle } \\
& \mathrm{R}=\text { load } \\
& \mathrm{F}_{\mathrm{s}}=\text { switching frequency }
\end{aligned}
$$

The capacitor values are designed from the formula given below,

$$
C=\frac{\delta V_{O}}{V_{r} R F_{S}}
$$

Where,

$\mathrm{V}_{\mathrm{o}}=$ Output Voltage

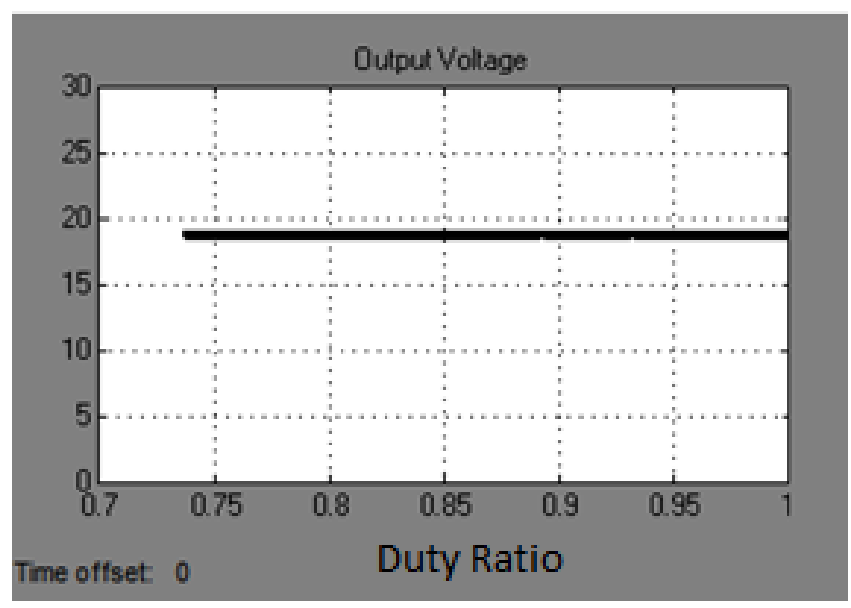

Fig-5: Output Voltage for Boost Converter

Theoretically, the switches are ideal so there are no losses in the circuit. But in simulation circuit switches are non-ideal, therefore losses will occurs in the output voltage Thus the comparison is shown in Fig.6

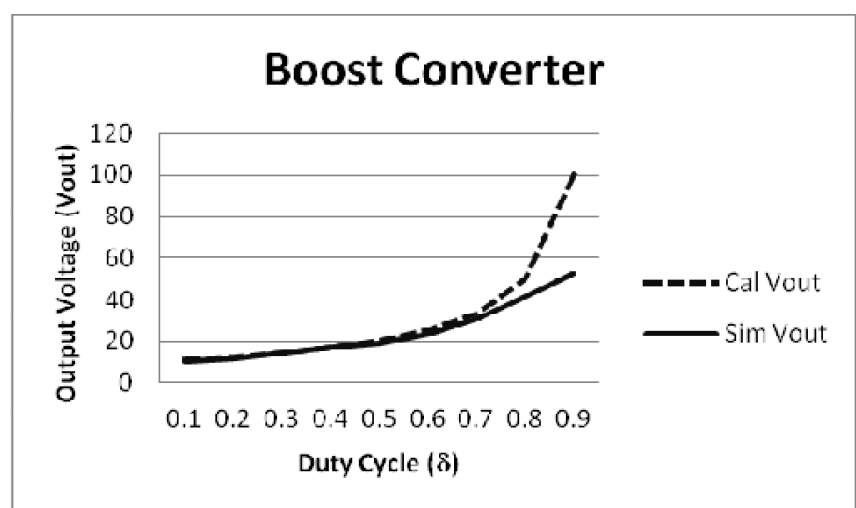

Fig-6: Calculated and Simulated Output Voltage for Boost Converter

\section{BOOST CONVERTER WITH CLD}

Boost converter is used to step up the given voltage to the desired voltage. By using CLD cell in boost converter the voltage stress on the switches can be reduced and can increase the capability to operate at high switching frequencies. The input to this converter may be from any DC source like rectifiers,solar panel,battaries etc,. Thecircuit diagram for Boost Converter with CLD cell is shown below,

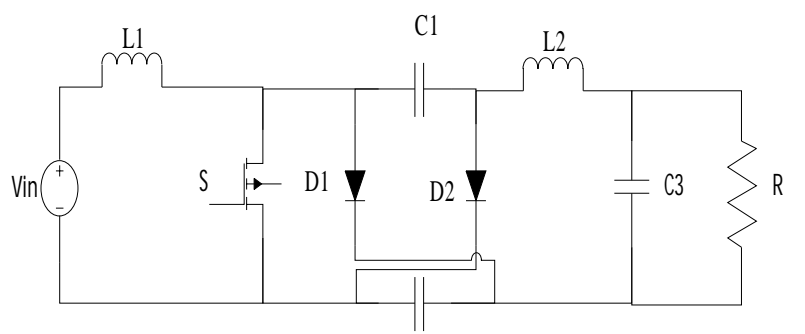

$\mathrm{C} 2$

Fig-7: Circuit Diagram for Boost Converter with CLD 


\section{Mode 1:}

Boost converter is used to step up the given voltage to the desired voltage. By using CLD cell in boost converter the voltage stress on the switches can be reduced and can increase the capability to operate at high switching frequencies. The input to this converter may be from any DC source like rectifiers, solar panel,battaries etc,. The circuit diagram for Boost Converter with CLD cell is shown below,

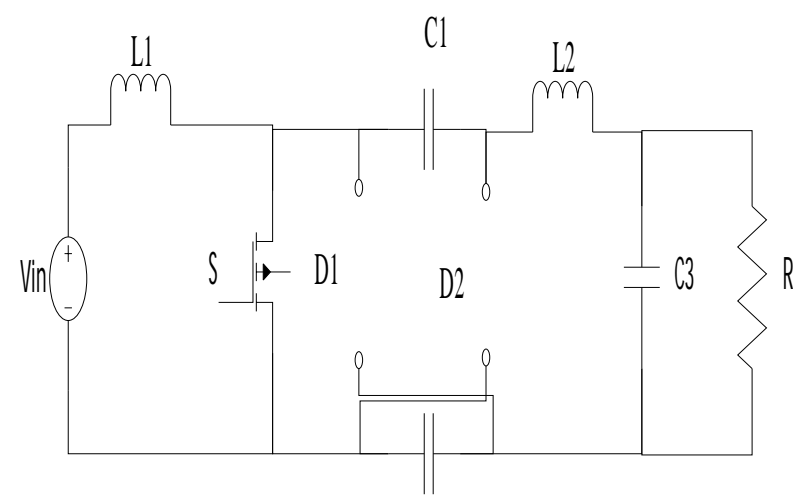

C2

Fig-8: Circuit Diagram for Mode 1 Operation of Boost Converter with CLD

\section{Mode 2:}

The switch is open and so the diodes become conducted due to discharge of capacitors. The energy stored in the inductor gets discharged through opposite polarities which charge the capacitor. The load current remains constant throughout the operation.
Fig-9: Circuit diagram for Mode 2 operation of Boost converter with CLD

\subsection{Equation Boost Converter with CLD}

Through Fig.8, and Fig.9, By applying the volt-second balance law the inductor L1 and L2 will following in equation

$V_{\text {in }} t_{\text {on }}+\left(V_{\text {in }}-V_{C 2}\right) t_{\text {off }}=0$ $\left[2 V_{c 2}-V_{o}\right] t_{o n}+\left[V_{c 2}-V_{o}\right] t_{o f f}=0$

$\frac{\mathrm{V}_{\mathrm{o}}}{\mathrm{V}_{\mathrm{in}}}=\frac{1+\delta}{1-\delta}$

The value of inductor $\mathrm{L}_{2}$ calculated from the following equation,

$L 2=\frac{\delta T R(\delta-1)}{1+\delta}$

The capacitor voltage $\mathrm{V}_{\mathrm{c} 3}$ is,

$V c 3=\frac{V o}{1-\delta}$

\subsection{Simulation Results for Boost Converter With CLD}

The boost converter with CLD is simulated with the input voltage of $10 \mathrm{~V}$. The switching frequency used is $1 \mathrm{kHz}$. The simulation circuit diagram for the quadratic boost converter is given below in Fig 10.
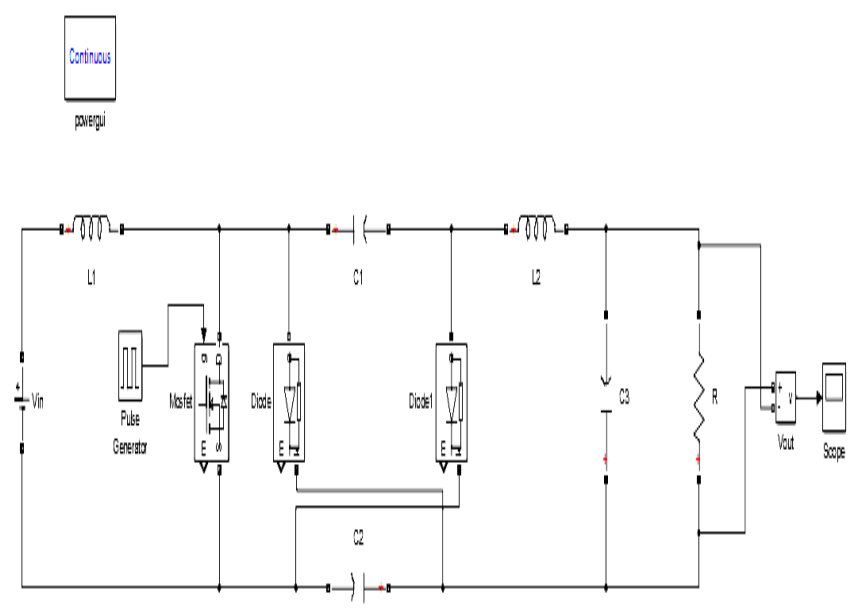

Fig-10: Simulation Circuit Diagram for Boost Converter with CLD

If $V_{S}=10 \mathrm{~V}, \delta=0.5$ the simulation output is $26 \mathrm{~V}$ for the same input voltage. The simulation output of boost converter with CLD is shown below in Fig. 11

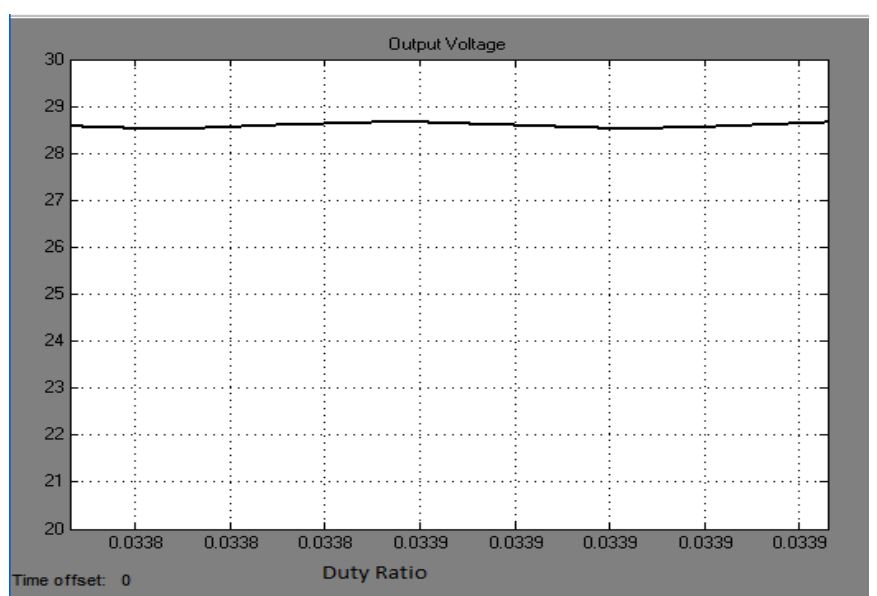

Fig-11: Output Voltage of Boost Converter with CLD 


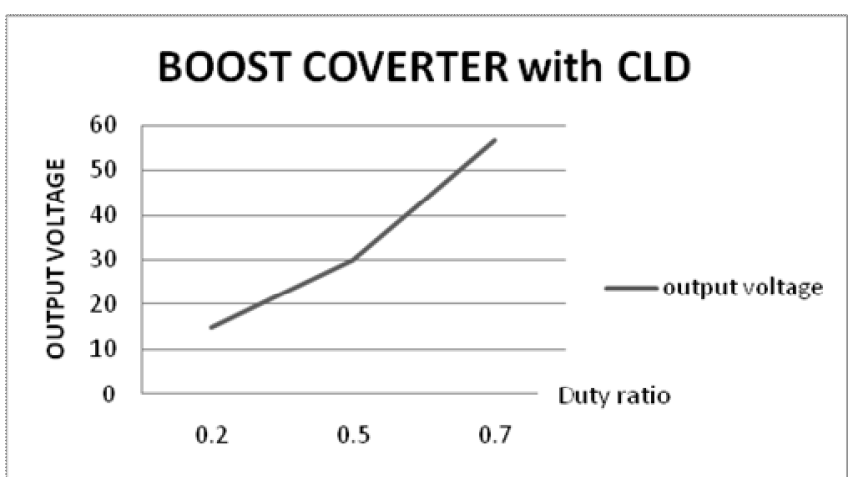

Fig-12: Calculated and Simulated Output Voltage for Boost Converter with CLD

\section{COMPARISON RESULTS}

For Boost converter on the basis of theoretical and simulated output it is verified that for the input voltage of $10 \mathrm{~V}$ the output get boosted only upto $20 \mathrm{~V}$ at duty ratio 0.5 . But in Boost converter with CLD for the same input voltage the output get boosted up to $26 \mathrm{~V}$ for same duty ratio.

Table-1: Output Analysis of Boost Converter

\begin{tabular}{|l|l|l|l|l|l|}
\hline \multirow{2}{*}{$\begin{array}{l}\text { Duty } \\
\text { Ratio }\end{array}$} & \multicolumn{4}{|l|}{ Boost Converter } \\
\cline { 2 - 6 } & $\begin{array}{l}\text { Input } \\
\text { Voltage } \\
(\mathrm{V})\end{array}$ & $\begin{array}{l}\text { Input } \\
\text { Current } \\
(\mathrm{A})\end{array}$ & $\begin{array}{l}\text { Output } \\
\text { Voltage } \\
(\mathrm{V})\end{array}$ & $\begin{array}{l}\text { Output } \\
\text { Current } \\
(\mathrm{A})\end{array}$ & Efficiency \\
\hline 0.2 & 10 & 3 & 11.63 & 1.173 & $45 \%$ \\
\hline 0.5 & 10 & 7.5 & 18.91 & 1.891 & $48 \%$ \\
\hline 0.7 & 10 & 14.9 & 30.57 & 3.057 & $62 \%$ \\
\hline
\end{tabular}

Table-2: Output Analysis of Boost Converter with CLD

\begin{tabular}{|l|l|l|l|l|l|}
\hline \multirow{2}{*}{$\begin{array}{l}\text { Duty } \\
\text { Ratio }\end{array}$} & \multicolumn{3}{|l|}{ Boost Converter with CLD } \\
\cline { 2 - 6 } & $\begin{array}{l}\text { Input } \\
\text { Voltage } \\
(\mathrm{V})\end{array}$ & $\begin{array}{l}\text { Input } \\
\text { Current } \\
(\mathrm{A})\end{array}$ & $\begin{array}{l}\text { Output } \\
\text { Voltage } \\
(\mathrm{V})\end{array}$ & $\begin{array}{l}\text { Output } \\
\text { Current } \\
(\mathrm{A})\end{array}$ & Efficiency \\
\hline 0.2 & 10 & 2.9 & 13.13 & 1.313 & $59 \%$ \\
\hline 0.5 & 10 & 10 & 26.19 & 2.619 & $68 \%$ \\
\hline 0.7 & 10 & 27 & 41.92 & 4.192 & $70 \%$ \\
\hline
\end{tabular}

Table-3: Efficiency Comparison

\begin{tabular}{|l|l|l|}
\hline \multirow{2}{*}{$\begin{array}{l}\text { Duty } \\
\text { Ratio }\end{array}$} & Efficiency \\
\cline { 2 - 3 } & Boost Converter & Boost Converter with CLD \\
\hline 0.2 & $45 \%$ & $59 \%$ \\
\hline 0.5 & $48 \%$ & $68 \%$ \\
\hline 0.7 & $62 \%$ & $70 \%$ \\
\hline
\end{tabular}

\section{Voltage stress on switches}

The switching pulse is given to the switches to transfer the maximum output to the load from the given input. Whenthe switching pulse is given to the switches then there will be some stress on the switches due to frequent turn on and turn off. The stress on the switches is shown below in Fig.13.

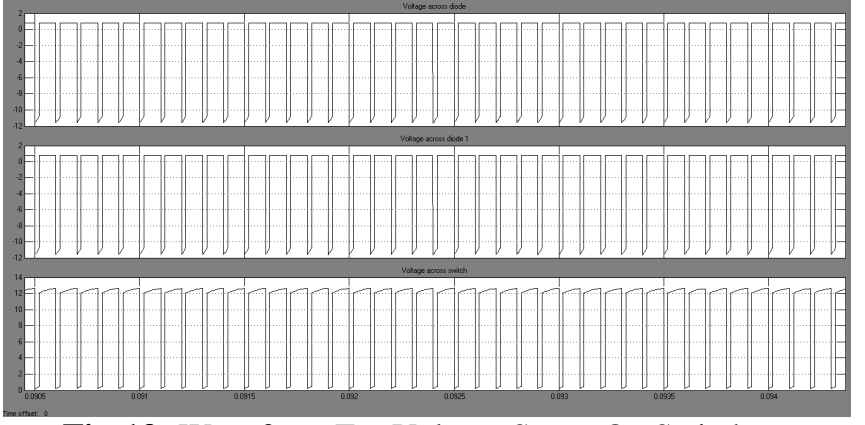

Fig-13: Waveform For Voltage Stress On Switches

\section{CONCLUSION}

The comparison results shows that Boost converter with CLD cell have better voltage characteristics then the Boost converter.It also reduced the switching losses and voltage stress result will be a high efficiency. Hence the Boost converter with CLD cell is more convenient than the conventional circuit.

\section{REFERENCES}

[1]. R. Kadri, J. P. Gaubert, G. Champenois, "Performance Analysis of Transformless Single Switch Quadratic Boost Converter for Grid Connected Photovoltaic Systems," IEEE Electrical Machines Conference., 2010, pp. 1-7.

[2]. Pranshu Agarwal, Rajeev Kumar Singh" A Modular Magnetically Coupled Quadratic Boost Converter for Microsource Applications" in IEEE at 7th IET International Conference on Power Electronics, Machines and Drives (PEMD 2014).

[3]. M. G. Ortiz-Lopez, J. Leyva-Ramos, L. H. DiazSaldierna, J. M. Garcia-Ibarra and E. E. CarbajalGutierrez" Current-mode control for a quadratic boost converter with a single switch"in Power Electronics Specialists Conference, 2007. PESC 2007. IEEE .

[4]. K.Tattiwong and C. Bunlaksananusorn,Analysis "Design and Experimental Verification of a Quadratic Boost Converter"in Proceedings 10th IEEE Region conference TENCON,2014.

[5]. Muhammad Aamir, Mahmood YounasShinwari, "Design, Implementation and Experimental Analysis of Two-Stage Boost Converter for Grid Connected Photovoltaic System" in Proceedings of 3rd IEEE International Conference on Computer Science and Information technology, 2010 .

[6]. K.H .Beena, Anish Benny"Analysis and Implementation of Quadratic

[7]. Boost Converter for NanogridApplications"in IJAREEIE Vol. 4, Issue 7, July 2015.

[8]. Mustafa A. Al-Saffar, Esam H. Ismail, and Ahmad J. Sabzali" High Efficiency Quadratic Boost Converter"

[9]. S. Park and S. Choi, "Soft-switched CCM boost converters with high voltage gain for high-power applications," IEEE Trans. Power Electron., vol. 25, no. 5, pp. 1211-1216, May 2010.

[10]. Q. Zhao, F. Tao, and F. C. Lee, "High-efficiency, high step-up dc-dc converters," IEEE Trans. on 
Power Electronics, vol. 18, no. 1, pp. 65-73, Jan. 2003.

[11]. B.-R. Lin, J.-Y. Dong and J.-J. Chen, "Analysis and Implementation of a ZVS/ZCS DC-DC Switching Converter with Voltage Step-Up," IEEE Trans. Ind. Electron., vol 58, no. 7, pp. 2962-2971, Jul. 2011.

\section{BIOGRAPHIES}

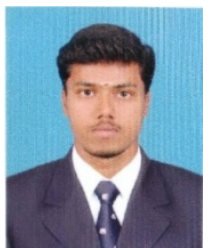

SELVAKUMAR. R ,He received B.E degree in Electrical \&Electronics Engineering from UIT (Anna University, Chennai)in 2014.He is currently pursuing M.E degree in power Electronics and Drives from Bannari Amman Institute of Technolgy, Sathyamangalam. His research interest include solar energy, Control System, Power Electronics.

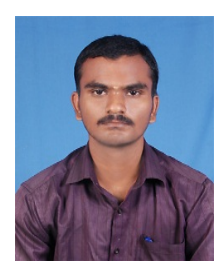

VIGNESH. C. J., He received B.E degree in Electrical \&Electronics Engineering from Hindustan College of Engineering and Technology (Anna University, Chennai)in 2014.He is currently pursuing M.E degree in power Electronics and Drives from Bannari Amman Institute of Technolgy, Sathyamangalam. His research interest include Control System, FEA analysis of Machines, Converters.

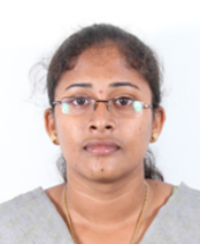

GAYATHRI DEIVANAYAKI. V. P, She received B.E degree in Electrical \& Electronics Engineering from SRIT(Anna University, Chennai) in 2014. She is currently pursuing M.E degree in power Electronics and Drives from Bannari Amman Institute of Technology, Sathyamangalam, Her research interest include power converters, Machines.

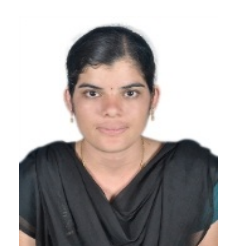

NAVEENA. P, She received B.E degree in Electrical \&Electronics Engineering from SSIET (Anna University, Chennai) in 2014. She is currently pursuing M.E degree in power Electronics and Drives from Bannari Amman Institute of Technology, Sathyamangalam, Her research interest include Control System, FACTS, Inverter. 